\title{
Arrest of glomerulopathy in diabetic dogs by improved glycaemic control
}

\author{
T.S. Kern and R.L.Engerman \\ Department of Ophthalmology, University of Wisconsin, Madison, Wisconsin, USA
}

\begin{abstract}
Summary. In order to assess the extent to which the progression of diabetic glomerulopathy can be arrested or reversed by improved glycaemic control, glomerular structure has been assessed in dogs randomly divided between a non-diabetic group and three alloxan diabetic groups: dogs assigned to poor glycaemic control for five years (PC), dogs assigned to good glycaemic control for five years (GC), and dogs assigned to poor glycaemic control for 2.5 years followed by good glycaemic control for 2.5 years $(\mathrm{P} \rightarrow \mathrm{GC})$. Glomerular volume, the fractional volume of mesangium as estimated by light microscopy and the thickness of glomerular basement membrane as estimated by electron microscopy were significantly greater than normal
\end{abstract}

at 2.5 years of poor glycaemic control, and were even greater at five years. Kidney weight and the frequency of glomerular obliteration were significantly greater than normal at five years of poor control. The development of these renal abnormalities was significantly inhibited if good glycaemic control was begun within the first weeks of diabetes. Good control following 2.5 years of poor control (group $\mathrm{P} \rightarrow \mathrm{GC}$ ) arrested the progression of the renal abnormalities, but no reversal of the lesions toward normal was apparent.

Key words: Diabetic nephropathy, diabetes, dog, kidney, glycaemic control.
Improved glycaemic control can reverse the elevated rates of glomerular filtration and albumin excretion toward normal in early diabetes, but the deterioration of renal function in late diabetic nephropathy reportedly is not slowed by intervention with good control [1-3]. Whether or not good glycaemic control can arrest or reverse existing structural abnormalities in diabetic kidney disease is not clear. In rats, good glycaemic control of as little as 2 months duration can reportedly arrest or even normalize glomerular lesions in diabetes [4-6].

Diabetic dogs develop a kidney disease similar to that characteristic of diabetic patients, including nephromegaly, mesangial expansion, glomerulosclerosis, albuminuria and haemodynamic abnormalities [7-11]. In the present study, the ability of good glycaemic control to prevent diabetic glomerulopathy has been compared to its efficacy in arresting or reversing existing glomerular damage.

\section{Materials and methods}

\section{Animals}

Healthy adult dogs of either sex were assigned at random to be made diabetic, or to be retained in a normal non-diabetic condition for comparison. Diabetes was produced by i.v. injection of alloxan monohydrate ( 50 to $60 \mathrm{mg} / \mathrm{kg}$ in citrate buffer, $\mathrm{pH} \mathrm{4.0)}$ ) following a 24-h fast. Kidneys were not protected from exposure to alloxan. Animals having persistent hyperglycaemia and glucosuria 1-2 months after alloxan were divided at random among 3 diabetic groups identified according to their intended degree of glycaemic control. The following groups were compared: (1) poor glycaemic control of diabetes for five years (group PC), (2) good glycaemic control of diabetes for five years (group GC), (3) poor glycaemic control for 2.5 years followed by an additional 2.5 years of good glycaemic control (group $P \rightarrow G C$ ), and (4) non-diabetic controls.

Poor glycaemic control was achieved by ad libitum feeding and a single injection of insulin (NPH isophane suspension, Eli Lilly and Company, Indianapolis, Ind., USA) daily at dosages insufficient to prevent chronic hyperglycaemia and glucosuria. Dogs assigned to good glycaemic control received insulin twice daily (regular soluble insulin and NPH isophane suspension, both Eli Lilly and Company; 09.00 and 19.00 hours) and measured quantities of food immediately after in an effort primarily to eliminate glycosuria, and thus to correct the hyperglycaemia [12]. In the $\mathrm{P} \rightarrow \mathrm{GC}$ group, a wedge of kidney cortex was obtained at 2.5 years of poor glycaemic control (for comparison with kidney obtained at autopsy at five years) immediately before initiating good glycaemic control. Ocular tissue also was collected at 2.5 years and five years [13].

The dogs were housed in metabolism cages, and 24-h samples of urine were collected daily for determination of urine volume and for semi-quantitative evaluation of glycosuria (Tes-tape; Eli Lilly and Company). Quantitative assay of urine sugar (glucose oxidase) was performed at least twice weekly, and whenever glucosuria was present in animals assigned to good control. Sugar-free days represented the number of days per 100 in which testing of the 24-h sample of urine with Tes-tape caused no generation of colour on the strip. Haemoglobin $\mathrm{A}_{1}\left(\mathrm{HbA}_{1}\right)$ was measured using commercial columns (Quick-Sep, Isolab, Akron, OH, USA) two to four times per year. Blood glucose was measured throughout the day $(08.00,14.00,20.00$, 08.00 hours) at intervals of three to four months. Values reported for $\mathrm{HbA}_{1}$ and for blood and urine glucose are the average over the entire period of study ( 2.5 years or five years, as appropriate). Additional assays of blood glucose were obtained from individual animals as needed to manage their medical problems, and are not included in the table shown. 
Kidney samples were obtained surgically or at autopsy from animals anaesthetized with sodium pentobarbital $(25 \mathrm{mg} / \mathrm{kg})$. Tissue wedges collected from mid-kidney were fixed for light microscopy in $10 \%$ neutral formalin, and for electron microscopy in $4 \%$ phosphate buffered glutaraldehyde followed by post-fixation in $1 \%$ osmium tetroxide.

\section{Morphology}

All analyses were done in a masked fashion. Thickness of glomerular peripheral capillary basement membrane was determined ultrastructurally by the orthogonal intercept method $[8,14]$ using ultrathin sections of the centermost glomerulus from three different epon blocks. Approximately 20 fields were photographed per glomerulus at a final magnification of $17500 \times$, resulting in an average of 189 basement membrane intercepts per glomerulus. Paraffin sections $(4 \mu \mathrm{m})$ of kidney were stained with haematoxylin and eosin, and with periodic acid-Schiff (PAS) and haematoxylin. Glomerular volume [15] and the fraction of glomerular tuft area occupied by PAS-positive material were determined quantitatively using point counting methods (100 point grid, $312 \times$ ) on paraffin-embedded tissue. The fractional volume of PAS-positive material was used as an estimate of fractional volume of mesangium, but includes also some basement membrane. Intensity of the PAS stain was not a factor in this measure. The number of consecutive glomeruli evaluated per animal was 35 for autopsy material, and averaged 25 (range 1035 ) for biopsy samples. Two dogs in the $\mathrm{P} \rightarrow \mathrm{GC}$ group lack paraffinembedded biopsy samples, and therefore epon-embedded biopsy tissue from these animals was used to estimate glomerular and mesangial volumes. For these two animals, glomerular volume at biopsy (formalin-fixed, paraffin-embedded tissue) was estimated from the ratio of glomerular volumes of glutaraldehyde-fixed, eponembedded tissue at biopsy and autopsy ( 10 to 26 sequential glomeruli in 6 to 10 blocks per sample) multiplied by autopsy glomerular volume of tissue prepared in formalin and paraffin ( 35 glomeruli per sample). Biopsy glomerular volume estimated this way in the four other $\mathrm{P} \rightarrow \mathrm{GC}$ animals averaged $75 \%( \pm 13$; SD) of the volume actually measured in formalin/paraffin-prepared tissue. The frequency of obliterated glomeruli ( $>80 \%$ sclerosed) at autopsy was determined from an average of 252 glomeruli per animal.

\section{Statistical analysis}

Due to the small number of animals in some groups, comparisons between groups were made using non-parametric methods (KruskalWallis and Mann-Whitney tests), and for comparisons between biopsy and autopsy samples from the same animals, by the Wilcoxon signed-ranks test. Some possible comparisons between groups were not important to the present study, and were not made. Data are reported as mean $\pm \mathrm{SD}$.

\section{Results}

\section{Glycaemic control}

Diabetic dogs assigned to group PC developed chronic hyperglycaemia, glycosuria, polyuria, and hyperphagia, and their mean $\mathrm{HbA}_{1}$ concentration throughout the five years of study was significantly greater than normal $(p<0.01$, Table 1$)$. The mean blood glucose between 08.00 and 20.00 hours was $20 \mathrm{mmol} / \mathrm{l} \pm 2$ (SD), and severe glycosuria was observed daily.

The twice daily injections of insulin in animals assigned to group GC reduced the blood glucose to approximately normal, and reduced $\mathrm{HbA}_{1}$ to a value not significantly different from normal. Glycosuria was mild when present, and the urine remained sugar-free for a mean of 67 days per 100 days. The correction of hyperglycaemia was accompanied by decreases also of serum non-esterified fatty acid and total cholesterol to levels not significantly different from normal (data not shown).

In group $\mathrm{P} \rightarrow \mathrm{GC}, 2.5$ years of good glycaemic control followed 2.5 years of poor glycaemic control. Glycaemic control during the latter 2.5 years of diabetes (good control) was as "good" as that in animals of group GC. Likewise, glycaemic control during the initial 2.5 years in group $\mathrm{P} \rightarrow \mathrm{GC}$ (poor control) was as "poor" as in the animals of group PC kept five years in poor control.

\section{Morphology}

The fractional volume of PAS-positive stain in glomeruli (estimating fractional volume of mesangium) was significantly greater than normal in animals kept in poor glycaemic control for the full five years (Table 2). Group PC also had excessive glomerular volume, basement membrane thickness, frequency of obliterated glomeruli and kidney weight. The frequency of obliterated glomeruli differed greatly among individual members of the group, and ranged from 1 to $27 \%$ of glomeruli per animal.

Good glycaemic control from the onset of diabetes (group GC) inhibited the development of the above glomerular abnormalities. Group GC differed significantly from group PC, and not from normal animals, with respect to glomerular volume, fractional area occupied by PAS-positive material, basement membrane thickness, the frequency of obliterated glomeruli and kidney weight (Table 2).

Kidneys biopsied after poor glycaemic control of 2.5 years duration showed significantly greater fractional

Table 1. Glycaemic control achieved in prospectively identified treatment groups (mean $\pm \mathrm{SD}$ )

\begin{tabular}{|c|c|c|c|c|c|}
\hline & \multirow[t]{2}{*}{ Normal } & \multirow{2}{*}{$\begin{array}{l}\text { Poor } \\
\text { control } \\
(\mathrm{PC})\end{array}$} & \multirow{2}{*}{$\begin{array}{l}\text { Good } \\
\text { control } \\
\text { (GC) }\end{array}$} & \multicolumn{2}{|l|}{$\mathrm{P} \rightarrow \mathrm{GC}$} \\
\hline & & & & $\begin{array}{l}\text { Poor } \\
\text { control }\end{array}$ & $\begin{array}{l}\text { Good } \\
\text { control }\end{array}$ \\
\hline $\begin{array}{l}\text { Duration } \\
\text { (years) }\end{array}$ & 5 & 5 & 5 & $\underbrace{2.5}_{5}$ & 2.5 \\
\hline (n) & 16 & 10 & 9 & 6 & 6 \\
\hline $\begin{array}{l}\text { Haemoglobin } \\
\mathrm{A}_{1}(\%)\end{array}$ & $\begin{array}{l}6.4 \\
\pm 0.7\end{array}$ & $\begin{array}{l}10.9 \\
\pm 1.1\end{array}$ & $\begin{array}{l}6.3 \\
\pm 0.9\end{array}$ & $\begin{array}{l}11.2 \\
\pm 0.9\end{array}$ & $\begin{array}{l}6.7 \\
\pm 0.8\end{array}$ \\
\hline \multicolumn{6}{|l|}{$\begin{array}{l}\text { Plasma glucose } \\
(\mathrm{mmol} / \mathrm{l})\end{array}$} \\
\hline 08.00 hours & $\begin{array}{l}4.4 \\
\pm 0.5\end{array}$ & $\begin{array}{l}20 \\
\pm 3\end{array}$ & $\begin{array}{l}6.1 \\
\pm 1.7\end{array}$ & $\begin{array}{l}19 \\
\pm 0.7\end{array}$ & $\begin{array}{l}5.7 \\
\pm 0.7\end{array}$ \\
\hline 14.00 hours & $\begin{array}{l}4.0 \\
\pm 0.7\end{array}$ & $\begin{array}{l}18 \\
\pm 3\end{array}$ & $\begin{array}{l}4.6 \\
\pm 1.7\end{array}$ & $\begin{array}{l}18 \\
\pm 1.9\end{array}$ & $\begin{array}{l}4.3 \\
\pm 0.5\end{array}$ \\
\hline 20.00 hours & $\begin{array}{l}4.3 \\
\pm 0.7\end{array}$ & $\begin{array}{l}21 \\
\pm 3\end{array}$ & $\begin{array}{l}4.1 \\
\pm 0.8\end{array}$ & $\begin{array}{l}21 \\
\pm 2.3\end{array}$ & $\begin{array}{l}3.4 \\
\pm 0.3\end{array}$ \\
\hline $\begin{array}{l}\text { Glycosuria } \\
\mathrm{g} \cdot \text { day }^{-1} \cdot \mathrm{kg} \\
\text { body wt }\end{array}$ & 0 & $\begin{array}{l}10.8 \\
\pm 4.6\end{array}$ & $<1$ & $\begin{array}{l}10.2 \\
\pm 3.1\end{array}$ & $<2$ \\
\hline $\begin{array}{l}\% \text { sugar-free } \\
\text { days }\end{array}$ & 100 & 0 & 67 & 0 & 64 \\
\hline
\end{tabular}


Table 2. Ability of good glycaemic control to inhibit or arrest diabetes-induced abnormalities in kidney weight and renal morphology in dogs (mean \pm SD)

\begin{tabular}{|c|c|c|c|c|c|}
\hline & \multirow{2}{*}{$\begin{array}{l}\text { Nor- } \\
\text { mal }\end{array}$} & \multirow{2}{*}{$\begin{array}{l}\text { Poor } \\
\text { control } \\
\text { (PC) }\end{array}$} & \multirow{2}{*}{$\begin{array}{l}\text { Good } \\
\text { control } \\
\text { (GC) }\end{array}$} & \multicolumn{2}{|l|}{$\mathrm{P} \rightarrow \mathrm{GC}$} \\
\hline & & & & $\begin{array}{l}\text { Poor } \\
\text { control }\end{array}$ & $\begin{array}{l}\text { Good } \\
\text { control }\end{array}$ \\
\hline \multirow[t]{2}{*}{ Duration (years) } & 5 & 5 & 5 & 2.5 & 2.5 \\
\hline & & & & 2.5 & \\
\hline$(n)$ & 16 & 10 & 9 & 6 & 6 \\
\hline $\begin{array}{l}\text { Kidney weight } \\
\text { (g/kg of baseline } \mathrm{BW} \text { ) }\end{array}$ & $\begin{array}{l}2.5 \\
\pm 0.5\end{array}$ & $\begin{array}{l}4.0^{\mathrm{a}, \mathrm{b}} \\
\pm 0.6\end{array}$ & $\begin{array}{l}2.5 \\
\pm 0.6\end{array}$ & - & $\begin{array}{l}3.1^{c} \\
\pm 0.7\end{array}$ \\
\hline $\begin{array}{l}\text { Glomerular tuft } \\
\text { vol }\left(\mu \mathrm{m}^{3} \times 10^{6}\right)\end{array}$ & $\begin{array}{l}1.7 \\
\pm 0.4\end{array}$ & $\begin{array}{l}4.7^{\mathrm{a}, \mathrm{b}} \\
\pm 1.1\end{array}$ & $\begin{array}{l}2.1 \\
\pm 0.6\end{array}$ & $\begin{array}{l}3.0^{\mathrm{a}, \mathrm{c}} \\
\pm 1.1\end{array}$ & $\begin{array}{l}2.9^{\mathrm{a}, \mathrm{c}} \\
\pm 1.1\end{array}$ \\
\hline $\begin{array}{l}\text { PAS + material } \\
\text { ( } \% \text { of glomerulus) }\end{array}$ & $\begin{array}{l}33 \\
\pm 5\end{array}$ & $\begin{array}{l}48^{\mathrm{a}, \mathrm{b}} \\
\pm 5\end{array}$ & $\begin{array}{l}34 \\
\pm 4\end{array}$ & $\begin{array}{l}40^{\mathrm{a}, \mathrm{c}} \\
\pm 8\end{array}$ & $\begin{array}{l}40^{\mathrm{a}, \mathrm{c}} \\
\pm 6\end{array}$ \\
\hline $\begin{array}{l}\text { Obliterated glomeruli } \\
\text { (\% of all glomeruli) }\end{array}$ & $\begin{array}{l}1 \\
\pm 1\end{array}$ & $\begin{array}{l}9^{a, b} \\
\pm 8\end{array}$ & $\begin{array}{l}2 \\
\pm 3\end{array}$ & - & $\begin{array}{l}4^{\mathrm{a}} \\
\pm 5\end{array}$ \\
\hline $\begin{array}{l}\text { Capillary basement } \\
\text { membrane width (nm) }\end{array}$ & $\begin{array}{l}361 \\
\pm 76 \\
(n=9)\end{array}$ & $\begin{array}{l}644^{\mathrm{a}, \mathrm{b}} \\
\pm 79 \\
(n=7)\end{array}$ & $\begin{array}{l}416 \\
\pm 34 \\
(n=6)\end{array}$ & $\begin{array}{l}464^{\mathrm{a}, \mathrm{c}} \\
\pm 92\end{array}$ & $\begin{array}{l}470^{c} \\
\pm 122\end{array}$ \\
\hline
\end{tabular}

a $p \leq 0.05$ or less compared with normal; ${ }^{\mathrm{b}} p<0.05$ or less compared with Diabetes good control; ${ }^{c} p<0.05$ or less compared with Diabetes poor control; $d$ Used as an estimate of mesangium

area of PAS-positive material in glomeruliwhen compared with kidneys from normal animals studied at five years; the fraction of glomerulus occupied by PAS-positive material exceeded the range of normal in four of the six animals in group $\mathrm{P} \rightarrow \mathrm{GC}$. Glomerular volume after 2.5 years of poor control also was found to be significantly greater than normal, but the limited number of glomerular profilesfound in some biopsy samples leaves the volume measurement in those animals more subject to sampling error. Thickening of glomerular basement membrane at 2.5 years of poor control was of borderline significance $(p=0.05)$.

Groups $\mathrm{P} \rightarrow \mathrm{GC}$ and $\mathrm{PC}$ were compared at five years duration to evaluate the extent to which the progression of the glomerulopathy was arrested by improved glycaemic control. After five years of diabetes, significantly less glomerular and mesangial expansion, basement membrane thickening and nephromegaly were found in the $\mathrm{P} \rightarrow \mathrm{GC}$ group than in the PC group (Table 2). The frequency of glomerular obliteration in the $\mathrm{P} \rightarrow \mathrm{GC}$ group likewise tended to be less than in group PC, but the difference did not achieve statistical significance between these small groups.

No evidence of reversal or progression of the glomerular lesions during good glycaemic control was apparent in the $\mathrm{P} \rightarrow \mathrm{GC}$ group. Fractional volume of PAS-positive material, and thickness of capillary basement membrane were not different after the delayed intervention with good glycaemic control (i. e., at five years) than they were prior to initiation of good control (i.e., after 2.5 years of poor control). Glomerular volume likewise seemed not to change during the intervention with good control, similar conclusions being reached if volumes calculated for the two $\mathrm{P} \rightarrow \mathrm{GC}$ animals lacking paraffin-embedded biopsy tissue (see Methods) were omitted, or if volumes at biopsy and autopsy were compared for these two animals using epon-embedded tissue.

\section{Discussion}

Good glycaemic control inhibits the onset and development of glomerular histopathology in diabetic rats [16-18] and dogs if instituted soon after the onset of diabetes. Comparable studies have not been reported for human subjects. The ability of good glycaemic control to reverse or arrest existing kidney disease in diabetes is less clear.

Reversal of diabetes-induced alterations in kidney structure have been investigated heretofore in rats, and not in other animals. Mesangial expansion secondary to 6-8 months of poorly controlled diabetes in rats has been observed to disappear following pancreas or islet transplants [4-6]. Questions have been raised regarding the suitability of the rat as a model for diabetic kidney disease, due in part to unreliability of that species to develop mesangial lesions like those characteristic of diabetic patients [19].

In contrast to the findings in rats, modest mesangial enlargement caused by 2.5 years of poor control in our dogs shows no evidence of reversal during the subsequent 2.5 years of good glycaemic control. In diabetic patients, modest mesangial expansion and basement membrane thickening showed little tendency to reverse following pancreas transplantation, and glomerular volume did not diminish [20]. Glomerulopathy present in kidneys donated by a diabetic patient has been said to disappear following transplantation of the kidneys into non-diabetic recipients [21], but little data was presented to support the claim, and a report that good glycaemic control reduced enlarged kidneys in diabetic patients [22] has not been confirmed $[1,23]$.

Arrest of structural abnormalities in diabetic kidney disease possibly represents an early step in a process leading to reversal of lesions. Progression of glomerular lesions in diabetic patients reportedly has been arrested by pancreas transplantation. Patients having a pancreas transplant were found later to have smaller mesangial and glomerular volumes than patients not receiving a pancreas transplant [20], but a possibility that glycaemic control was unequal between the two groups prior to pancreas transplant was not ruled out. The pancreas transplantation showed no significant effect on glomerular basement membrane thickening. In the present study of diabetic dogs, intervention with good control (group $\mathrm{P} \rightarrow \mathrm{GC}$ ) appeared to arrest mesangial expansion, nephromegaly and basement membrane thickening.

Thickened capillary basement membranes in glomeruli of diabetic patients [20], rats $[14,24]$ or dogs resists reversal toward normal during intervention with good glycaemic control. In contrast, the capillary basement membrane of skeletal muscle reportedly becomes thinner upon improvement of glycaemic control [25-29]. Factors determining basement membrane thickness apparently vary among tissues.

The response of the kidney to intervention with good glycaemic control seems different from that exhibited by the retina. Kidneys from dogs in group $\mathrm{P} \rightarrow \mathrm{GC}$ were already abnormal by 2.5 years of poor control with respect to glomerular volume, fractional volume of PAS-positive material (predominantly mesangium) and basement 
membrane width, and the further progression of these abnormalities was arrested during the intervention with good glycaemic control. In contrast, little or no retinopathy was present in the same animals at 2.5 years of poor glycaemic control (group $\mathrm{P} \rightarrow \mathrm{GC}$ ), yet the retinal microangiopathy surprisingly became pronounced during the subsequent 2.5 years of good control [13]. Only thickening of capillary basement membrane in the retina appears to have been arrested by the intervention, in contrast to the marked increase in the number of microaneurysms, pericyte ghosts, acellular capillaries and haemorrhages during the delayed period of good control. Diabetic retinopathy progresses after intervention with good glycaemic control seemingly also in humans [30]. Other evidence likewise suggests that the pathogenesis of diabetic retinopathy and kidney disease might be dissimilar. Non-diabetic dogs fed a galactose-enriched diet for five years develop a marked diabetic-like retinopathy [31], yet show no structural evidence of kidney disease except for glomerular basement membrane thickening $[7,8]$.

Acknowledgements. This study was supported in part by Public Health Service research grant EY00300 from the National Eye Institute, and by a research grant from the Juvenile Diabetes Foundation International. We sincerely appreciate the skillful technical assistance of M. Garment and M. Larson.

\section{References}

1. Wiseman MJ, Saunders AJ, Keen H, Viberti GC (1985) Effect of blood glucose control on increased glomerular filtration rate and kidney size in insulin-dependent diabetes. N Engl J Med 312: $617-621$

2. Feldt-Rasmussen B, Mathiesen ER, Deckert T (1986) Effect of two years of strict metabolic control on the progression of incipient nephropathy in insulin-dependent diabetes. Lancet II: 1300-1304

3. Viberti GC, Bilous RW, Mackintosh D (1983) Long-term correction of hyperglycemia and progression of renal failure in insulin-dependent diabetics. Br Med J 286: 578-602

4. Steffes MW, Brown DM, Basgen JM, Mauer SM (1980) Amelioration of mesangial volume and surface alterations following islet transplantation in diabetic rats. Diabetes 29:509-515

5. Orloff MJ, Yamanaka N, Greenleaf GE, Huang YT, Huang DG, Leng XS (1986) Reversal of mesangial enlargement in rats with long-standing diabetes by whole pancreas transplantation. Diabetes 35: 347-354

6. Petersen J, Ross J, Rabkin R (1988) Effect of insulin therapy on established diabetic nephropathy in rats. Diabetes 37: 1346-1350

7. Kern TS, Engerman RL (1987) Kidney morphology in experimental hyperglycemia. Diabetes $36: 244-249$

8. Engerman RL, Kern TS (1989) Hyperglycemia and development of glomerular pathology: diabetes compared with galactosemia. Kid Int 36: 41-45

9. Kern TS, Engerman RL (1988) Urinary protein excretion rates in experimentally diabetic dogs and experimentally galactosemic dogs. Diabetologia 31: 928-932

10. Kern TS, Engerman RL (1989) Renal hemodynamics in dogs with diabetes or galactosemia. Diabetes 38 [Suppl 2]: 93 Abstract

11. Bloodworth JMB Jr (1965) Experimental diabetic glomerulosclerosis. II. The dog. Arch Pathol 79: 11.3-125

12. Engerman RL, Bloodworth JMB Jr, Nelson S (1977) Relationship of microvascular disease in diabetes to metabolic control. Diabetes 26: 760-769

13. Engerman RL, Kern TS (1987) Progression of incipient diabetic retinopathy during good glycemic control. Diabetes 36 : 808-812
14. Steffes MW, Brown DM, Basgen JM, Matas AJ, Mauer SM (1979) Glomerular basement membrane thickness following islet transplantation in the diabetic rat. Lab Invest 41: 116-118

15. Bilous RW, Mauer SM, Sutherland DER, Steffes MW (1989) Mean glomerular volume and rate of development of diabetic nephropathy. Diabetes 38: 1142-1147

16. Rasch R (1979) Prevention of diabetic glomerulopathy in streptozotocin diabetic rats by insulin treatment. Glomerular basement membrane thickness. Diabetologia 16: 319-324

17. Rasch R (1979) Prevention of diabetic glomerulopathy in streptozotocin diabetic rats by insulin tratment. The mesangial region. Diabetologia 17: 243-248

18. Rasch R (1979) Prevention of diabetic glomerulopathy in streptozotocin diabetic rats by insulin treatment. Kidney size and glomerular volume. Diabetologia 16: 125-128

19. Second International Symposium on Kidney Disease of Diabetes Mellitus (1989) Summary Recommendations. National Institutes of Health, Bethesda, MD

20. Bilous RW, Mauer SM, Sutherland DER, Najarian JS, Goetz FC, Steffes MW (1989) The effects of pancreas transplantation on the glomerular structure of renal allografts in patients with insulin-dependent diabetes. N Engl J Med 321: 80-85

21. Abouna GM, Al-Adnani MS, Kremer GD, Kumar SA, Daddah SK, Kusma G (1983) Reversal of diabetic nephropathy in human cadaveric kidneys after transplantation into non-diabetic recipients. Lancet II: $1274-1276$

22. Mogensen CE, Andersen MJF (1975) Increased kidney size and glomerular filtration rate in untreated juvenile diabetes: normalization by insulin-treatment. Diabetologia 11: 221-224

23. Christiansen JS, Gammelgaard T, Tronier B, Svendsen TA, Parving HH (1982) Kidney function and size in diabetics before and during initial insulin treatment. Kidney Int 21: 683-688

24. Gotzche O, Gundersen HJG, Osterby R (1981) Irreversibility of glomerular basement membrane accumulation despite reversibility of renal hypertrophy with islet transplantation in early experimental diabetes. Diabetes 30:481-485

25. Sosenko JM, Miettinen OS, Williamson JR, Gabbay KH (1984) Muscle capillary basement membrane thickness and longterm glycemia in Type I diabetes mellitus. N Engl J Med 311: 694-698

26. Raskin P, Pietri AO, Unger R, Shannon, Jr WA (1983) The effect of diabetic control on the width of skeletal-muscle capillary basement membrane in patients with Type I diabetes mellitus. $\mathrm{N}$ Engl J Med 309: 1546-1550

27. Camerini-Davalos RA, Velasco C, Glasser M, Bloodworth, Jr JMB (1983) Drug-induced reversal of early diabetic microangiopathy. N Engl J Med 309: 1551-1556

28. Rosenstock J, Challis P, Sttowig S, Raskin P (1988) Improved diabetes control reduces skeletal muscle capillary basement membrane width in insulin-dependent diabetes mellitus. Diab Res Pract 4: 167-175

29. Camerini-Davalos RA, Velasco C, Glasser M, Bloodworth, Jr JMB (1988) Sulfonylurea-induced decrease of muscle capillary basement membrane thickness in diabetes. Diab Res Pract 5: $113-123$

30. Dahl-Jorgensen K, Brinchmann-Hansen O, Hanssen KF, Ganes T, Kierulf P, Smeland E, Sandvik L, Aagenaes O (1986) Effect of near normoglycemia for two years on the progression of early diabetic retinopathy, nephropathy, and neuropathy: the Oslo study. Br Med J 293: 1195-1199

31. Engerman RL, Kern TS (1984) Experimental galactosemia produces diabetic-like retinopathy. Diabetes 33:97-100

Received: 13 December 1989

and in revised form: 12 April 1990

T. S. Kern, PhD

Department of Ophthalmology

University of Wisconsin

1300 University Avenue

Madison, Wisconsin 53706

USA 